\title{
Using the journal BMJ Case Reports to promote the publication of clinical case reports
}

\author{
Blanca San José Montano \\ See end of article for author's affiliation.
}

DOI: http://dx.doi.org/10.3163/1536-5050.104.4.015

\begin{abstract}
Objective: The study updates and enhances clinicians' knowledge about clinical case reports (CCRs) and encourages publication of such articles.
\end{abstract}

Methods: The author developed and offered a session about BMJ Case Reports to medical and surgical departments in the University Hospital of Móstoles. The session reviewed the contents and add-on services of the journal, conventional and alternative indicators of journal quality, use of CCRs to share valuable clinical lessons, and manuscript preparation and submission.

Results: The main result of these sessions was submission of eight CCRs to BMJ Case Reports, of which four were accepted. One submitting author was invited to serve as peer reviewer for the journal. Other clinicians are preparing five new CCRs for submission to BMJ Case Reports or other journals.

Conclusions: The learning sessions were successful in promoting writing and publication of CCRs. Young staff and postgraduate residents seemed especially encouraged to publish CCRs that had already been presented in their departmental sessions. As a librarian, I gained experience in CCR publication and reinforced my position as an essential supporter of the hospital's teaching and publishing activity.

Keywords: Clinical Case Reports, Health Sciences Libraries, Health Sciences Librarians, Publishing, Scientific Journals, Medical Education, Continuing Medical Education, Research Informationist

Clinical case reports (CCRs) are detailed reports that describe the diagnosis or management of one or more patients [1]. Their purpose, according to Sir William Osler, is to "produce valuable education and research resources" [2]. CCRs have a long tradition in medical literature [3] and have been published as a regular section in many medical journals. However, the 1980s saw a rise in negative opinions of CCRs due to their low level in the hierarchy of evidence [4] and their lack of specificity for medical decision making [5]. Since the late 1990s, however, CCRs have been increasingly published, with the genre adapting to new challenges $[5,6]$ and the launch of new journals specifically devoted to publishing CCRs.

The University Hospital of Móstoles in Spain is a second-level general hospital (295 beds) with a very active clinical practice (145 postgraduate residents). Also, since 2014, it has been an important undergraduate teaching site for 2 universities (approximately 138 students). CCRs derived from health care activities are routinely used as a teaching tool in every department. However, in recent years, clinicians at our hospital have almost stopped publishing CCRs in medical journals: 24 CCRs were published from 2005 to 2014, with only 3 published between 2012 and 2014.

The health sciences library of the University Hospital of Móstoles supports health care, teaching, and research performed in the hospital. As its librarian and research informationist, I participate in the entire research, teaching, and learning lifecycles [7] and encourage lifelong learning and publishing based on the hospital's health care activity. In 2015, a new journal subscription provided a new opportunity for clinicians at the hospital. The journal BMJ Case Reports (ISSN: 1757-790X; casereports.bmj. com) publishes a large volume of CCRs in all branches of medicine and has a unique business 
model in which institutional subscribers can establish a fellowship that waives individual fellowship fees for affiliated authors. I used the introduction of this new journal to update and enhance clinicians' knowledge about CCRs and to encourage them to publish this type of article.

\section{METHODS}

I developed a learning session to raise clinicians' awareness of BMJ Case Reports and to use its specific features to update and reinforce knowledge about medical publishing. I offered this session to all medical and surgical departments (thirty-four units) in their own continuing education programs. The session was divided into four parts:

1. Journal contents and add-on services: alerts, really simple syndication (RSS) feeds, videos, blogs, and top-rated articles.

2. Indicators of journal quality and increasing publication impact: indexing in major international databases; journal impact factor (although BMJ Case Reports does not have an impact factor because case reports are rarely cited, therefore its impact factor would be expected to be low); alternative metrics ("altmetrics") of the use and impact of scientific publications based on attention in mass media, blogs, Twitter, Facebook, and so on; and the open access movement and deposit of manuscripts into publicly accessible repositories to improve their reach.

3. CCRs as an avenue for sharing valuable clinical lessons: CCRs potentially have a high sensitivity for detecting novelty $[4,5]$. They serve as the first line of evidence [6] and can be powerful tools for discovering new diseases, unusual clinical syndromes, disease associations, and unusual side effects of therapy or responses to treatments $[8,9]$. In its "Instructions for Authors," BMJ Case Reports provides a variety of cases and topics that they consider to provide the most valuable clinical lessons.

4. Manuscript preparation and submission process: To strengthen the level of evidence of CCRs and satisfy editors' expectations, the quality of case reporting must be high, and authors must be careful not to generalize, overinterpret, or misinterpret their observations. For this reason, BMJ Case Reports requests a precise, focused primary message and a well-organized and structured report, submitted using a required manuscript template $[5,10]$. Both the patients' informed consent and their perspectives on their diseases or management are very important.

\section{RESULTS}

From January to December 2015, I gave learning session in twelve departments. The session was favorably received by participating physicians, who reported that they updated and refreshed their knowledge of medical publishing and journal quality indicators and other metrics. Young staff and postgraduate residents seemed especially encouraged to publish CCRs that had already been presented in their departmental sessions.

The main result of these learning sessions was the submission of eight manuscripts to BMJ Case Reports. Four manuscript were accepted after revisions that were requested by the editors and peer reviewers [11-14]. The revisions generally pertained to improving writing style and article structure and extending the discussion, and they were an important learning experience for the authors. The other four manuscripts were rejected because they described very common cases that did not have clear teaching points or that were similar to previously published CCRs in BMJ Case Reports. Furthermore, one submitting author was asked to serve as a peer reviewer for another manuscript. The four published CCRs were written by members of the Department of Internal Medicine in collaboration with members of the Departments of Pathology and Oncology. At present, other clinicians are preparing five new CCR manuscripts: three for BMJ Case Reports and two for other journals. Furthermore, as a librarian, I gained experience in CCR publication and reinforced my position as an essential supporter of the hospital's teaching and publishing activity.

\section{DISCUSSION}

Although my intention is to encourage the publication of CCRs, the criteria for evaluating research activity published by the Spanish National Evaluation of Research Activity Committee does not support this goal. In their 2014 [15] and 2015 [16] recommendations, they state that "as a general rule, clinical cases, conference papers and letters to the editor should not be considered as ordinary contributions." However, this statement underestimates the importance of formal medical communication based on real, day-to-day clinical practice. In addition to their power to detect novelty, 
CCRs are also a convenient genre for neophytes to take their first steps in medical writing [3]. Arguably, new criteria that acknowledge the impact of CCRs may increase the visibility of this type of publication.

\section{ACKNOWLEDGMENTS}

I thank Dr. Manuel Varela for his translation support and advice. I also thank the editorial staff at the Journal of the Medical Library Association, particularly Katherine Akers, for providing significant editorial assistance.

\section{COMPETING INTERESTS}

The author has no competing interests.

\section{REFERENCES}

1. Gopikrishna V. A report on case reports. J Conserv Dent. 2010 Oct;13(4):265-71. DOI: http://dx.doi.org/10. 4103/0972-0707.73375.

2. Chelvarajah R, Bycroft J. Writing and publishing case reports: the road to success. Acta Neurochir (Wien). 2004 Mar;146(3):313-6; discussion 316.

3. Morris BA. The importance of case reports. CMAJ. 1989 Nov 1;141(9):875-6.

4. Vandenbroucke JP. In defense of case reports and case series. Ann Intern Med. 2001 Feb 20;134(4):330-4.

5. Nissen T, Wynn R. The clinical case report: a review of its merits and limitations. BMC Res Notes. 2014 Jan;7:264. DOI: http://dx.doi.org/10.1186/1756-0500-7-264.

6. Albrecht J, Werth VP, Bigby M. The role of case reports in evidence-based practice, with suggestions for improving their reporting. J Am Acad Dermatol. 2009 Mar;60(3):412-8. DOI: http://dx.doi.org/10.1016/j.jaad. 2008.10.023.

7. Jaguszewski JM, Williams K. New roles for new times: transforming liaison roles in research libraries.

Washington, DC: Association of Research Libraries; 2013. 8. Nissen T, Wynn R. The history of the case report: a selective review. JRSM Open. 2014 Apr;5(4):

2054270414523410. DOI: http://dx.doi.org/10.1177/

2054270414523410.

9. Carey JC. The importance of case reports in advancing scientific knowledge of rare diseases. Adv Exp Med Biol. 2010 Jan;686:77-86. DOI: http://dx.doi.org/10.1007/978-90481-9485-8_5.

10. BMJ Case Reports [Internet]. [cited 3 Feb 2016].

$<$ http://casereports.bmj.com $>$.
11. García Carretero R, Manotas-Hidalgo M, Romero Brugera M, El Bouayadi Mohamed L. Pleural effusion of malignant aetiology: cell block technique to establish the diagnosis. BMJ Case Rep. 2016 Mar 18. DOI: http://dx.doi. org/10.1136/bcr-2016-215140.

12. García Carretero R, Romero Brugera M, RebolloAparicio N, El Bouayadi Mohamed L. Primary bone metastasis as first manifestation of an unknown primary tumour. BMJ Case Rep. 2015 Sep 3. DOI: http://dx.doi. org/10.1136/bcr-2015-211302.

13. García Carretero R, Romero Brugera M, RebolloAparicio N, Rodeles-Melero J. Dysphagia and aspiration as the only manifestations of a stroke. BMJ Case Rep. 2016 Feb 11. DOI: http://dx.doi.org/10.1136/bcr-2015213817.

14. García Carretero RC, Sanchez-Redondo J, BarrioAlonso MJ, Lopez-Marti MP. Lung carcinoma presenting as a solitary, painless frontal bone lump. BMJ Case Rep. 2015 Dec 16. DOI: http://dx.doi.org/10.1136/bcr-2015212038.

15. BOE No290. Resolución de 26 de noviembre de 2014, de la Comisión Nacional Evaluadora de la Actividad Investigadora, por la que se publican los criterios específicos aprobados para cada uno de los campos de evaluación [Internet]. Agencia Estatal Boletín Oficial del Estado; 2014 [cited 1 Feb 2016]. p. 98204. <https://www. boe.es/boe/dias/2014/12/01/pdfs/BOE-A-2014-12482.

pdf $>$.

16. BOE no 286. Resolución de 26 de noviembre de 2015, de la Comisión Nacional Evaluadora de la Actividad Investigadora, por la que se publican los criterios específicos aprobados para cada uno de los campos de evaluación [Internet]. Agencia Estatal Boletín Oficial del Estado; 2015 [cited 1 Feb 2016]. p. 113060. <https://www. boe.es/boe/dias/2015/11/30/pdfs/BOE-A-2015-12970. pdf $>$.

\section{AUTHOR'S AFFILIATION}

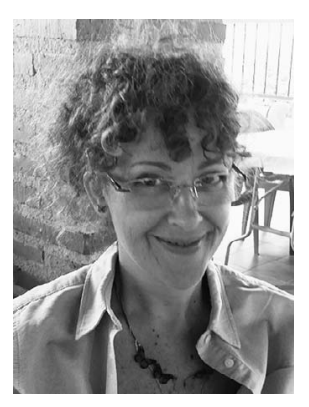

Blanca San José Montano, blanca.sanjose@salud.madrid. org, Health Sciences Librarian, Hospital Universitario de Móstoles, Rio Júcar s/n, Móstoles 28935, Madrid, Spain

Received March 2016; accepted May 2016 